\title{
Ergonomic aspects simulation digital online: an educational game proposal to promote environmental education
}

\author{
Arbex, D.F, Jappur, R. Selig, P and Varvakis, G. \\ ${ }^{a}$ Universidade Federal de Santa Catarina - Pós-Graduação em Engenharia e Gestão do Conhecimento (EGC) \\ Campus Universitário Reitor João David Ferreira Lima. Bairro: Trindade - Cidade: Florianópolis - Estado: Santa \\ Catarina. CEP: 88040-970. País: Brasil.
}

\begin{abstract}
This article addresses the ergonomic criteria that guide the construction of an educational game called Environmental Simulator. The focus is on environment navigation considering aspects of content architecture and its esthetics functionality.
\end{abstract}

Keywords: ergonomics, usability, graphic interface, navigation, educational game.

\section{Introduction}

The awakening of global consciousness to the issue of sustainability has been caused by a "wake-up call" of scientists around the world, that our future depends on the ability to change habits. Today, despite huge efforts and social and environmental initiatives, in therms of sustainability, there is still a great difficulty of breaking words into practice. In this context, by identifying the concentration ofenvironmental impacts promoted by human actions on buildings, it was conceived the idea of a virtual environment called Environmental Simulator (ES). The ES was designed to guide children and teenagers in their activities in a residence. This technology arose from the need to educate people on the various environmental impacts generated in buildings such as the production of waste,energy and water.

Based on the ES, the aim of this paper is to point the visual and the ergonomic aspects of this technological tool for Environmental Education directed to public school students with online access. By its utilization, the simulator attempts to demonstrate to users not only environmental impacts but an equivalent action to minimize them or even alternatives to mitigate them.
A systematic review was made through databases Scopus and Science Direct available at "Portal Capes" focusing on terms design and ergonomic. It was emphasized the relevance of the interaction between man and machine mediated by a virtual learning environment and/or educational game and design development of graphical user interface and navigation.

\section{Environmental Simulator: a tool for environmental education}

The Environmental Simulator is a tool for environmental education developed from the analysis of other virtual simulators (benchmark). Research has shown that there are other consumer-oriented simulators to the environment however it was found that most of these simulators deal only with one of the subject areas broached in this project. Therefore, the relevance of the project is guided by the fact that the ES broach more than one area resulting in an integrated environment for teaching and learning. The methodology used in the software design and its teaching practical application focuses on the interdisciplinary field of environmental education, for primary schools of the public schools of "Grande Flori- 
anopolis". The target audience consists of elementary school students but outreach to society at large. Its purpose is to support the practice of conscious consumption in buildings.

\section{Project development stages}

The system configuration was constructed according to the proposed ergonomics standards. According to the Brazilian Association of Ergonomics - ABERGO (2011) the term is a discipline oriented toward a systemic approach related all aspects of human activity. This dimension involves work activities from a holistic approach to the whole field of action of discipline in their physical, cognitive, social, organizational and environmental factors.

The aspects that were considered for the development of the system are primarily the cognitive aspects related to mental processes such as perception, memory, reasoning and motor response as they affect interactions among humans and other elements of a system. Topics relevant to this article are concerned, more specifically on two aspects: interactions human/system and decision making.

So the first step of the project focuses on user interactions with the environment. This interaction was constructed based on a survey with questions arranged in a game format. Students score and respond according to the decision-making regarding the appropriate way to their context of use. For each question were assigned ranging from the best alternative to the worst possible scenario of use. The one chosen to be the best scenario is directly related to the user action in the most economical use of energy in a residential environment. For each alternative were calculated energy consumption and/or water and waste (liquids and solids) and how each alternative generates $\mathrm{CO}_{2}$. At the end, the results present how much energy was consumed and produced, how much water was spent or how many wastes were discarded. At the end of the answers, there is an indication how many trees must be planted by the user to neutralize and reduce the consumption of them in a direct cause-effect relationship.

The second stage was characterized by the design of the environment in which strategies were defined. An example of these strategies could be formal and informal meetings with the contractor's technical teams (programmers and web designers) to validate the ergonomics, the interface and the design. The result of these meetings allowed the alignment of ideas and the definition of the following steps for the development phase of ergonomic design:

- Content architecture and user interface;

- Scenario development (residence);

- Definition of script and character (questionnaire);

- Visual identity and logo of the simulator;

The article emphasizes the area of ergonomics taking into account the architectural aspects of the content and the creation of graphical user interface related to navigation, to conduction and to user feedback outlined in sub-sections.

\subsection{Content architecture and user interface}

The relationship governed by the interface is semantic and characterized by meaning and expression. The word interface itself evokes cartoons of animated icons and colored bins on the move. In its simplest sense, the word interface refers to the software that brings form to the interaction between users and the computer (Johnson, 2001, p. 18).

The experiment of interaction is an empirical technique of ergonomic validation. The technique is performed with the user in order to confirm hypotheses of barriers to interaction and/or identify problems at various levels related to the use of the software (Cataplan et al.).

Since this is a very broad technique, the aim of this paper is not to present all relevant ergonomic criteria, but discuss its relevance in some respects. One aspect focused on the user interaction with the system is guided by the feedback. The feedback is a conduction usability criterion that evaluates the quality of immediate feedback to user actions. This criterion relates to the system responses to their actions. These entries can be a simple press of a button or a full list of commands. In all cases, the computer answers must be provided quickly, with appropriate and consistent steps and "timing" for each type of transaction. Anyway, a quick answer must be provided with information about the requested transaction and its result.

The browsing of the system was build based on the design of the content architecture and based in the context of interface use. This criterion is fundamental to being the heart of the browsing system. The architecture relates how the contents of the environment is provided, making their understanding easier regarding the use of cognitive resources (how information is written or the use of illustrations) and how it becomes available at different levels in a structure (Silvino and Abraham, 2003). This browsing is also 
characterized by another criterion which is the functional aesthetics of the system that has a language with playful color, references and metaphors accessible to children and teenagers as shown in Figure 1.

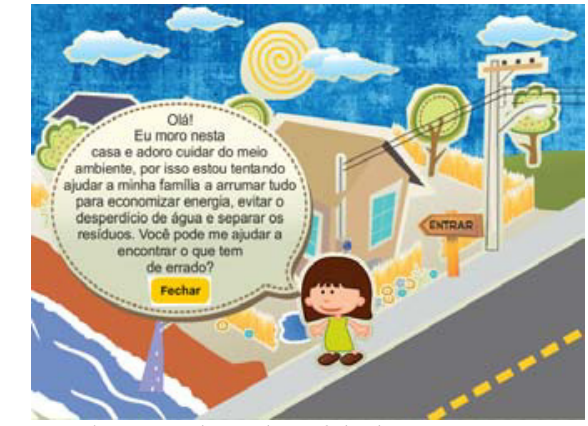

Figure 2. Floor plan of the house. Source:

http://www.meensina.org.br/site/simulador/ - Accessed on december, 05 of 2011.

The character begins navigating and dialogue with users. It guides the user into the environment or game scenario, suggesting the participation through identification of available elements.

\subsection{Scenario development}

The scenario was designed to tell an interactive story that happens inside the house. The interactions begin with a character that needs help to avoid waste of water and energy and also needs help to separate waste. Upon entering the residence the simulator shows a floor plan of all environments that the user must pass in linear steps of navigation. Thus begins the process of questions and answers about each room of this home. The order of rooms start, respectively as follows: the living room, the kitchen room, the laundry room, the master bedroom, the bathroom, the children's room and an outdoor area as shown in Figure 2.

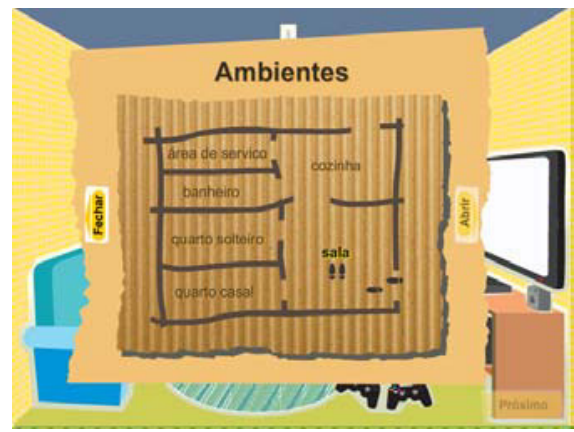

Figure 2. Floor plan of the house. Source: http://www.meensina.org.br/site/simulador/ Accessed on december, 05 of 2011.

The floor plan offers the navigation map of the house environments. In each room of the house, users are able to recognize and interact with several elements. By clicking on a given element, a window pops up with questions related to the decision made by the user. Every time the user clicks over an element and responds a question, the element is marked with a red line wrapped on it.

\subsection{Defining script and character}

It is understood that, in the field of ergonomics and pedagogy, learning the system, or operate the system and learning mediated by the system are two different things. It is assumed that these two dimensions in the HCI relationship (Human Computer Interaction) are closely linked (Catapan et al.). The script in an educational game is responsible for defining the content and user interactions with the system (instructional design). Table number one brings an example of an ES situation:

Table 1. Example of an ES script. Source: Arbex et al., (2011).

\section{Situation 1:}

The television is turned on and no one is watching it. What should you do?

\begin{tabular}{|ll|}
\hline 1) & Nothing! It's great to keep the television on! \\
\hline 2) & $\begin{array}{l}\text { Change the channel, because then someone might } \\
\text { want to watch! }\end{array}$ \\
\hline 3$)$ & $\begin{array}{l}\text { Pick up the remote control and turn off the televi- } \\
\text { sion, right? }\end{array}$ \\
\hline 4) & $\begin{array}{l}\text { Pick up the remote control and put the T.V. on } \\
\text { standby (just the little standby light is on). }\end{array}$ \\
\hline 5) & $\begin{array}{l}\text { Turn off the television and ask for an adult to un- } \\
\text { plug, for only thus conserving energy! }\end{array}$ \\
\hline
\end{tabular}


The result of the scripts enabled the definition of the following requirements:

- Simulator scope (in accordance with the general objective of the project);

- Set of the house environments (living room, kitchen room, bathroom, laundry room, double bedroom, single bedroom and outdoor area);

- Set of the scoring criteria;

- Set wrong situations and possible choices to avoid them.

The next step was to define the concept of the ES logo.

The interaction model developed for the ES involves perceptual and cognitive contact with the user. The user then browses the rooms of the house checking for possible "errors" that may be occurring in a given environment. These possible errors are detected when the quiz is available in a dialog box. This game metaphor with questions and answers contain relevant information regarding the educational context, because it indicates what is being wasted and used incorrectly (Figure 3).

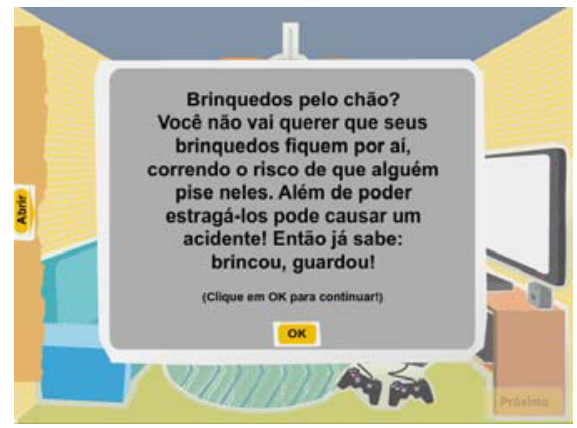

Figure 3.Question about toys scattered all over. Source:http://www.meensina.org.br/site/simulador/ - Accessed on december, 05 of 2011.

The screen shows an environment (room) and suggests actions that should be conducted by the user. The language teaching was defined according to the intended audience. The situations have been tested and validated with children aged 4 to 10 years old, as we shall see in the next section.

\subsection{Visual identity and ES logo}

The definition of the logo is a significant step in the project because it identifies the product. It is related to the visual identity of the environment as part of the aesthetic to make the experience enjoyable to the user. At this stage, it was assembled a design team that started off with a briefing (over data acquisition of the project) and a brainstorming. The pro- posal was to maintain a visual identity that would encompass environmental education (Figure 4).

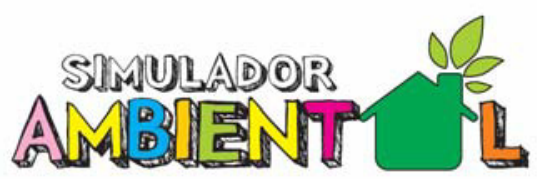

Figure 4. ES logo. Source: the authors (2011).

The proposal was to develop a logo that had a ludic language suitable for children and teenagers. Examples could be the use of more than five colors and typography with traits like pencil sketches over notebook paper. The logo colors were applied and worked in the color palette of the house environments in order to standardize and bring indoors coherence.

\section{Testing and validation}

Testing and validation of the SA functionality were made by a team of three people (designers and developers) and applied to 10 children (04 years to 10 years old). The focus of the analysis was based on children's interactions with the environment, still in prototype phase. Additional criteria for assessing environment navigability pointed to three other relevant criteria (Sarmet Silvino, 2002):

- System features - refers to the equipment quality or the equipment capability for internet access. It allows different resources to make the content more understanding by the user. The technologies used must be compatible with the most common ones found on the net.

- Content architecture - relates to how content is displayed, making comprehension easier regarding the use of cognitive resources (how information is written or the use of illustrations) and how it is made available (at various levels in a single structure).

- Functional aesthetics - these are proportion issues like balance, harmony in terms of traits, writing style and colors that can facilitate or hinder the user's browser.

Based on three relevant criteria it was considered the need of some aesthetics improvements and content adequacy. While children were playing and participating, evaluators wrote down the points for navigation and functionality of buttons: [OK], [OPEN], [CLOSED]. Use the buttons helps the user to under- 
stand the structure of the type of formatted content in a unique structure in linear sequence.

From other observations improvements have been made over the analysis, as an example, the environment design. Colors and some aspects of the house environment that characterize the design of the environment needed adjustments and better illustrations of the elements for a greater recognition by users. The tests also showed that black characters and gray background needed clarity and appropriateness of language for the intended audience.

\section{Conclusion}

The tests showed relevant ergonomics issues regarding the navigability and user interaction with the environment. In the process it was realized that the analysis of ergonomic criteria in virtual environments for teaching and learning provide a critical look at their performance and better ways of use, especially in the case of an educational media for children. It was made explicit, guiding content items, actions and activities of the public verifying the importance in helping them during the navigation through the environment. It also highlights the aesthetics from a design perspective, to assist visually and ease the use, of colors and traits expressed by illustrations.

\section{References}

[1] ABERGO Associação Brasileira de Ergonomia. 2011. Endereço eletrônico: http://www.abergo.org.br/internas.php?pg=o que e ergonomi a - Acesso em 08|12|2011.

[2] CATAPLAN Araci Hack; CORNÉLIO Filho Plínio; SOUZA Antonio Carlos D; THOMÉ Zeina Rebouças Corrêa; Cybis Walter De Abreu. Ergonomia em software educacional: A possível integração entre usabilidade e aprendizagem. In: Atas do II Workshop sobre fatores humanos em sistemas computacionais. Campinas: UNICAMP. 1999. Disponível em $<$ http://www.unicamp.br/ ihc99/Ihc99/AtasIHC99/art24.pdf> Acesso em 07 dez 2011.

[3] JOHNSON, S. Cultura da interface: como o computador transforma nossa maneira de criar e comunicar. Rio de Janeiro: Zahar. 2001

[4] SARMET, M. M. e SILVINO, A. M. D. Elaboração de um instrumento para avaliação de páginas de internet: a perspectiva do usuário. Em: ABERGO 2002 - VII Congresso Latino-Americano, XII Congresso Brasileiro de Ergonomia. Anais do ABERGO 2002. Recife: ABERGO, 2002. Pôster 040. 1. CD-ROM.

[5] SILVINO, A. M. D. \& ABRAHÃO, J. I. Navegabilidade e inclusão digital: navegabilidade e competência. Revista de Administração de Empresas, RAE-Eletrônica. (2). 2003. Acesso em 07 dez 2011. 